\title{
Generation of Mass Tags by the Inherent Electrochemistry of Electrospray for Protein Mass Spectrometry
}

\author{
Christophe Roussel, Loïc Dayon, Niels Lion, Tatiana C. Rohner,* \\ Jacques Josserand, Joël S. Rossier, ${ }^{+}$Henrik Jensen, ${ }^{\ddagger}$ \\ and Hubert H. Girault \\ Laboratoire d'Electrochimie Physique et Analytique, Institut des Sciences et Ingénierie Chimiques, \\ Ecole Polytechnique Fédérale de Lausanne, Lausanne, Switzerland
}

We present herein a review of our work on the on-line electrochemical generation of mass tags toward cysteine residues in peptides and proteins. Taking advantage of the inherent electrochemical nature of electrospray generated from a microfabricated microspray emitter, selective probes for cysteine were developed and tested for on-line nonquantitative mass tagging of peptides and proteins. The nonquantitative aspect of the covalent tagging thus allows direct counting of free cysteines in the mass spectrum of a biomolecule through additional adduct peaks. Several substituted hydroquinones were investigated in terms of electrochemical properties, and their usefulness for on-line mass tagging during microspray experiments were assessed with L-cysteine, peptides, and intact proteins. Complementarily, numerical simulations were performed to properly understand the respective roles of mass transport, kinetics of electrochemical-chemical reactions, and design of the microspray emitter in the mass tagging overall efficiency. Finally, the on-line electrochemical tagging of cysteine residues was applied to the analysis of tryptic peptides of purified model proteins for protein identification through peptide mass fingerprinting. (J Am Soc Mass Spectrom 2004, 15, 1767-1779) (C) 2004 American Society for Mass Spectrometry

$\mathrm{I}$ $n$ the recent years, microsystems have received a special attention in analytical chemistry [1, 2]. For example, analytical separations such as capillary electrophoresis (CE) [3, 4], two-dimensional electrokinetic separations [5], liquid chromatography (LC) [6], reaction and detection microchambers [7-9] have been implemented in the microfluidic format. More recently, analytical microfluidic systems have caught interest in the particular field of proteomics [10, 11] because of the high analytical constraints demanded by this field, namely the low amount of sample usually available, the high complexity of the initial protein mixture, and the need for high-throughput analysis [12]. The potential success of analytical systems also lies in the low production costs, opening the way for single use and contamination-free analytical devices. One particular category of microfluidic

Published online October 28, 2004

Address reprint requests to Prof. H. H. Girault, Laboratoire d'Electrochimie Physique et Analytique, Institut des Sciences et Ingénieries Chimiques, Ecole Polytechnique Fédérale de Lausanne, CH-1015 Lausanne, Switzerland. E-mail: hubert.girault@epfl.ch

* Current address: Analytical and Imaging Sciences, Novartis Institutes for Biomedical Research, Lichtstrasse 35, CH-4002 Basel, Switzerland.

+Current address: DiagnoSwiss SA, Route de l'Ile-au-Bois 2, CH-1870 Monthey, Switzerland.

$\ddagger$ Current address: Department of Analytical Chemistry, The Danish University of Pharmaceutical Sciences, DK-2100, Copenhagen, Denmark. systems that shows promise in proteomics is microfabricated micro- or nanospray emitters [13-20]. First, microfabrication robustness and reproducibility make available reliable micro- and nanospray emitters, with automation possibilities [21]. Second, the design flexibility provided by microfabrication allows the integration of different analytical processes on the same microfluidic device prior to delivery to the mass spectrometer, such as sample preparation [22-24], analyte separation [25-27], proteolytic digestion $[9,28]$, or even integration of the whole process [29].

The electrochemical nature of electrospray (ESI) was recognized in the early nineties [30], and experimentally proven by anodic corrosion of metallic electrospray capillaries. Since then, Van Berkel's group and others have comprehensively investigated the theoretical aspects of electrochemistry in electrospray [31-42] as well as made significant advances in electrochemical flow cell hyphenation with electrospray mass spectrometry (ESI-MS) [37, 43-46], and electrochemical derivatization strategies for analyte detection by ESI-MS [47-51]. Moreover, Bruins and coworkers have used EC-ESI-MS to study or mimic biologically relevant electrochemical reactions [52], such as phase I oxidative reactions in drug metabolism [53] or cytochrome P450 catalyzed reactions [54]. These analytical aspects of electrochem- 


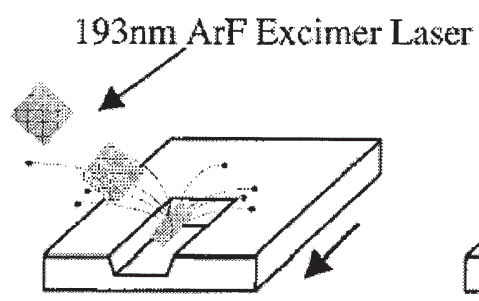

(a)

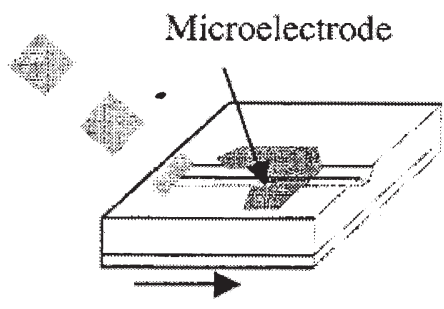

(d)

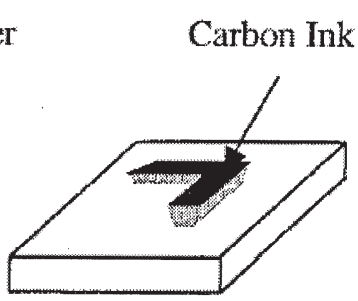

(b)

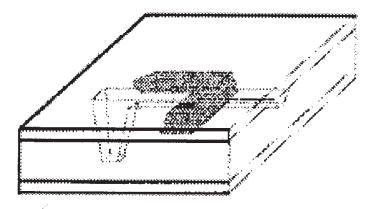

(e)

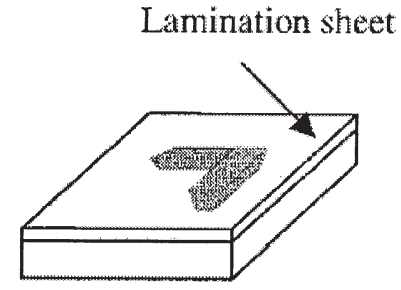

(c)

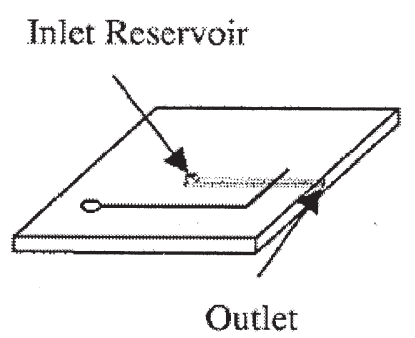

(f)

Figure 1. Scheme of the microfabrication process based on UV laser photoablation. The electrode conductive track is first ablated (a), then filled with carbon ink (b), cured and the chip is finally insulated with a lamination layer (c); a microchannel is drilled on the other side of the chip so as to be in contact with the conductive path and make a microelectrode (d), the chip is laminated to close the channel (e), resulting in the device shown in (f). Reprinted with permission from [17].

istry-mass spectrometry have been recently reviewed by Diehl and Karst $[55,56]$.

We have recently introduced a new strategy taking advantage of the electrochemical nature of electrospray to obtain more information from peptide and protein mass spectrometry experiments: electrochemical mass tags are infused through a microfabricated polymer microspray, and undergo oxidation (in positive ionization mode) or reduction (in negative ionization mode) on the microspray microelectrode (to which the electrospray voltage is applied) to become reactive toward a specific amino acid. In peptide and protein mass spectrometry, reactive nucleophilic amino acids, such as lysine [57] and cysteine [58], were chemically tagged to ease protein identification by peptide mass fingerprinting. As $89.3 \%$ of human proteins and $17 \%$ of their tryptic peptides possess at least one cysteine [59], the proposed methodology was targeted toward cysteine mass tagging. Based on recent works on the electrochemical detection of sulfides [60,61], thiols [62], and cysteine $[63,64]$ with quinone derivatives, we focused on the potential use of electrogenerated benzoquinones (coming from the oxidation of hydroquinones) able to react specifically with cysteine residues during electrospray mass spectrometric measurements. We present below a review of the different steps of the development of on-line electrochemical probes for cysteine mass tagging, from the proof of principle [65] to the elucidation of the tagging reaction mechanism [66], characterization of the microspray design influence on the tagging process [67], search for an optimal electrochemical probe [68], and final application to protein identification [69].

\section{Polymer Microspray Emitters for On-Line Electrochemical Tagging}

UV laser photoablation is a convenient process for the prototyping of microfluidic polymer systems [70-78]. Recently, a polymer microspray was designed in our laboratory with this process [17]. The microfabrication scheme described in Figure 1 leads to a microspray constituted of a microchannel $\left(35 \times 30 \mu \mathrm{m}^{2}\right.$ and $3.5 \mathrm{~cm}$ long, $2 \mathrm{~cm}$ from the electrode to the outlet) with an integrated carbon microelectrode. The raw microchip is then cut at its outlet into a triangular shape and placed in front of the MS as described in Figure 2 to act as a microspray emitter. The obtained microdevice was successfully applied to the routine analysis of biomolecules [17]. As the microelectrode integrated into the microspray presents a large area $\left(25 \times 70 \mu \mathrm{m}^{2}\right)$ compared with the volume of the microchannel (around $35 \mathrm{~nL}$ ), reaching an electrode surface-to-volume ratio of $50 \mathrm{~m}^{-1}$, the microspray acts as an efficient electrolytic cell. Thus, electrochemical reactions can easily occur at the integrated microelectrode surface and be monitored on-line by MS. As a first example, the possibility to tag the single free cysteine moiety of the target protein $\beta$-lactoglobulin A was demonstrated using the polymer 
a)
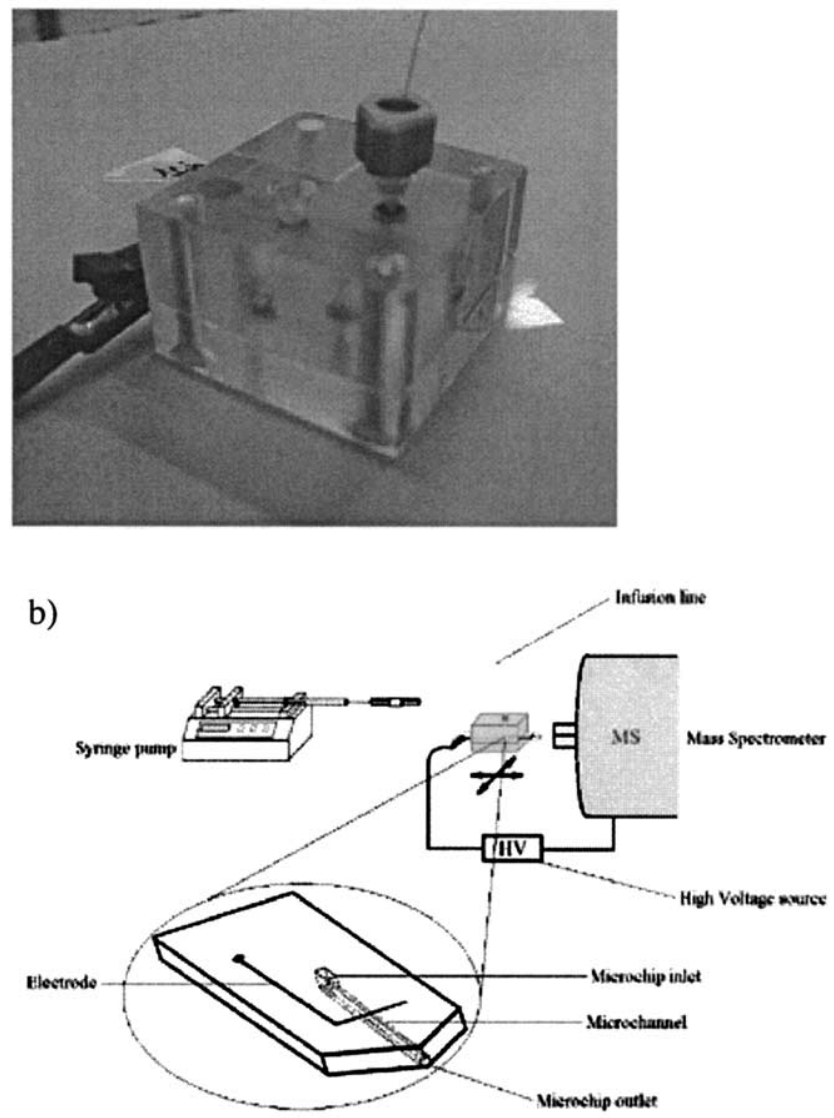

Figure 2. (a) Picture of the polymer microspray sandwiched in the microchip holder, allowing connection to an infusion capillary with low dead-volume connections and to the power supply for electrospray voltage delivery. (b) Scheme of operation of the microspray interface. microspray emitter, by simple infusion of hydroquinone together with the target protein [65]. The MS spectrum recorded in a classic MS spray medium $\left(\mathrm{CH}_{3} \mathrm{OH} / \mathrm{H}_{2} \mathrm{O} / \mathrm{CH}_{3} \mathrm{COOH}: 50 / 49 / 1 \%\right)$ presents two peak distributions corresponding to the signals of both tagged and untagged protein, confirming the presence of a single free cysteine within the protein, as shown in Figure 3 . The electrochemically induced tagging was first described to follow a general electrochemicalchemical-electrochemical (ECE) mechanism shown in Scheme 1. However, direct mass spectrometric investigation of the tagging reaction with the polymer microspray on a low-resolution mass spectrometer (LCQ Duo from Thermo Electron, San Jose, CA, in our case) did not allow to completely confirm the proposed mechanism, in particular the occurrence of the second oxidation step, which could be completely suppressed during the infusion experiment due to the short residence time of the biomolecule-hydroquinone adduct over the microelectrode (see numerical investigations below). In order to gain information on the electrochemical and chemical steps kinetics and to provide a good tagging reagent, the tagging of L-cysteine 3a' by several hydroquinones 1a-e was first studied by electrochemical methods.

\section{Electrochemical Tagging of L-Cysteine}

\section{Electrochemical Investigations of Tagging Reactions}

The electrochemical probes under study were substituted hydroquinones 1 bearing electrodonating, neutral or withdrawing groups inducing distinct electrochemical properties and chemical reactivities of the electrogenerated benzoquinones 2 (Scheme 1) toward L-cysteine and cysteine residues in peptides and proteins:

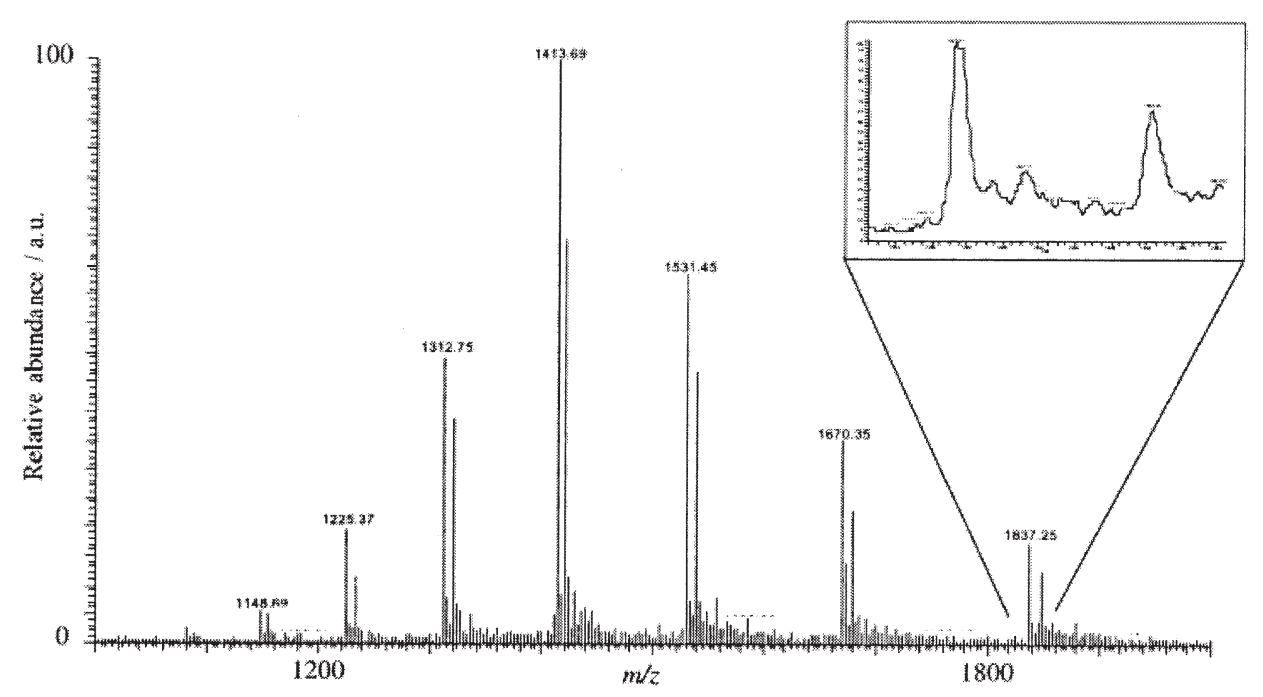

Figure 3. On-line electrochemical tagging of $\beta$-lactoglobulin A with hydroquinone 1c, in undegassed conditions, showing the peak distributions of untagged and tagged protein. Reprinted with permission from [65]. 
<smiles>[R]C1=CC(=O)C=CC1=O</smiles><smiles>[R]C1=CC(=O)C=CC1=O</smiles><smiles>[R]c1c(O)ccc(O)c1S</smiles><smiles>[R]c1c(O)ccc(O)c1SC</smiles><smiles>[R]C1=C([R])C(=O)C=CC1=O</smiles>

$$
\begin{aligned}
& \text { a: } \mathrm{R}^{1}=\mathrm{OCH}_{3} \\
& \text { b: } \mathrm{R}^{1}=\mathrm{CH}_{3} \\
& \text { c: } \mathrm{R}^{1}=\mathrm{H} \\
& \text { d: } \mathrm{R}^{1}=\mathrm{COOCH}_{3} \\
& \text { e: } \mathrm{R}^{1}=\mathrm{NO}_{2}
\end{aligned}
$$

Scheme 1. Mechanism of the electrochemical-chemical-electrochemical tagging of a cysteine moiety by hydroquinone derivatives.

2-methoxyhydroquinone $\mathbf{1 a}, 2$-methylhydroquinone $\mathbf{1 b}$ (electrodonating), hydroquinone 1c (neutral) and 2-carboxymethylhydroquinone 1d, 2-nitrohydroquinone 1e (withdrawing). First, Compound 1e was found to electropolymerize readily as previously mentioned in the literature [79] and was thus excluded from the study. Hydroquinones $\mathbf{1 a}-\mathbf{d}$ /benzoquinones $\mathbf{2} \mathbf{a}-\mathbf{d}$ proved to be stable at the cyclic voltammetry $(\mathrm{CV})$ time scale (Figure 4, thin lines). The long-term stability of these compounds was checked by UV and ${ }^{1} \mathrm{H}$ NMR studies [68]. From an electrochemical point of view, the hydroquinone CVs are irreversible, exhibiting a slow electrode kinetic process. Moreover, CV of pure L-cysteine $3 a^{\prime}$ revealed the nonelectroactive character of this compound in the experimental conditions $[66,68]$. The electrochemical tagging of L-cysteine by hydroquinones 1a-d was then investigated by cyclic voltammetry in the MS spray medium: the CVs obtained with pure hydroquinones (oxidation current intensity $I_{p}{ }^{0}$ ) were compared with those of the same hydroquinones in the presence of L-cysteine (oxidation current intensity $I_{p}$ ). As shown in Figure 4, the decrease or even disappear-

ance of the benzoquinone signals were attributed to their reaction with L-cysteine $3 \mathbf{a}^{\prime}$ and the relative current increase $I_{p} / I_{p}{ }^{0}$ (in presence/absence of L-cysteine $\left.3 \mathbf{a}^{\prime}\right)$ was explained by the oxidation of the formed adducts $4 \mathbf{a a}^{\prime}-\mathbf{d a} \mathbf{a}^{\prime}$ (second oxidation step in Scheme 1), occurring at a similar potential as the initial hydroquinone $1 \mathbf{a}-\mathbf{d}$ oxidation.

As the first electrochemical step involves a slow electron transfer, the kinetic constant of the homogeneous chemical step could not be accessed by standard techniques [80, 81]. In order to determine the homogenous kinetic constant $k$ corresponding to the chemical addition of electrogenerated benzoquinones $2 \mathbf{a}-\mathbf{d}$ onto L-cysteine $3 \mathbf{a}^{\prime}$, digital simulations of the hydroquinones $\mathbf{1 a}-\mathbf{d}$ CVs in the presence of L-cysteine $3 \mathbf{a}^{\prime}$ were performed using DigiSim software $[82,83]$ and compared to experimental CVs as shown in Figure 5a for hydroquinone 1c. To obtain more accurate values of the different kinetic constants $k$, the evolutions of the $I_{p} / I_{p}{ }^{0}$ ratios versus the $C V$ s scan rate were fitted to the experimental data, as shown in Figure $5 \mathrm{~b}$ for hydroquinone 1c. The value of $k$ was found to increase from 1a to 1d (see Table 1) [66, 68]. This result could easily be explained by the fact that the coupling reaction involves a nucleophile (L-cysteine $3 \mathbf{a}^{\prime}$ ): in that case, the presence of an electron donor group such as $\mathrm{CH}_{3}$ or $\mathrm{CH}_{3} \mathrm{O}$ increases the electronic density on the benzoquinone ring and is expected to decrease its reactivity toward L-cysteine addition. In contrast, the presence of an electroattracting group such as $\mathrm{COOCH}_{3}$ should result in a reverse effect. Moreover, the addition of L-cysteine $3 \mathrm{a}^{\prime}$ was found by ${ }^{1} \mathrm{H}$ NMR to occur at different positions (see Table 1), depending on the nature of the substituent $\mathbf{R}^{\mathbf{1}}$. Consequently, site-specific kinetic constants were derived from the global $k$ based on ${ }^{1} \mathrm{H}$ NMR results, in agreement with the predicted electron delocalization effect induced by the substituent group. In summary, the worst hydroquinone is 2-methoxyhydroquinone 1a whereas the most efficient is 2-carboxymethylhydroquinone $\mathbf{1 d}$. The kinetic behavior of the different hydroquinones determined by electrochemical methods was then further compared with the experimental on-line electrochemical tagging of L-cysteine during MS analysis.

\section{ESI-MS On-Line Electrochemical Tagging of L-Cysteine}

Based on the previously described electrochemical behavior of the different hydroquinones $\mathbf{1 a}-\mathbf{d}$, the efficiency of the on-line electrochemical tagging during infusion through the polymer microspray was investigated with L-cysteine $3 a^{\prime}$. In all cases, two peaks were clearly observed in the mass spectrum, for both the untagged and tagged L-cysteine, as shown in Figure 6. The ratios of peak intensities tagged/(untagged + tagged) were found to follow the order $\mathbf{1 b}<\mathbf{1 c}<\mathbf{1 a}<$ 1d, as summarized in Table 2. Once corrected for ionization efficiencies (in particular for hydroquinone 1a), the tagging efficiencies were found to be in good 
a)
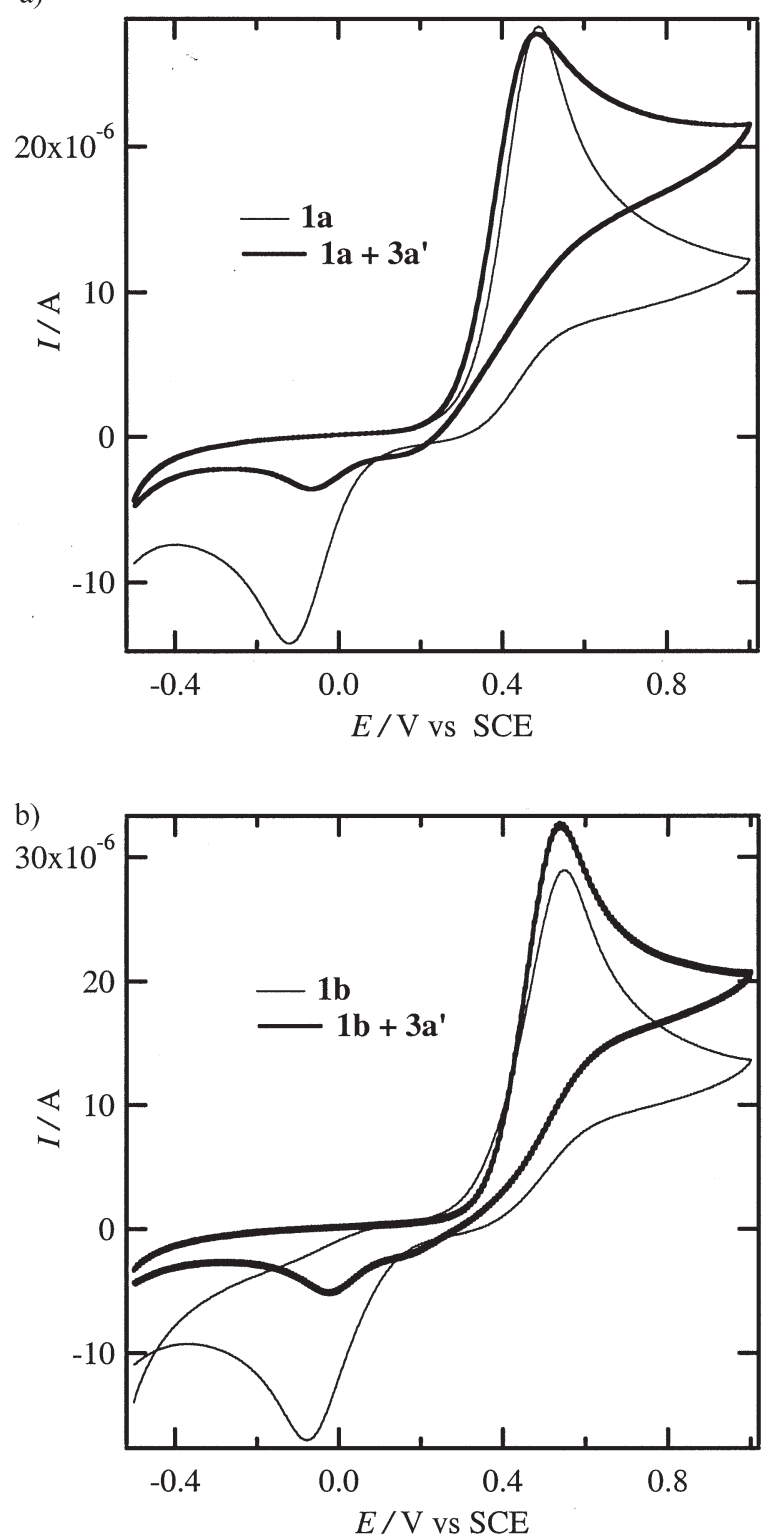

c)
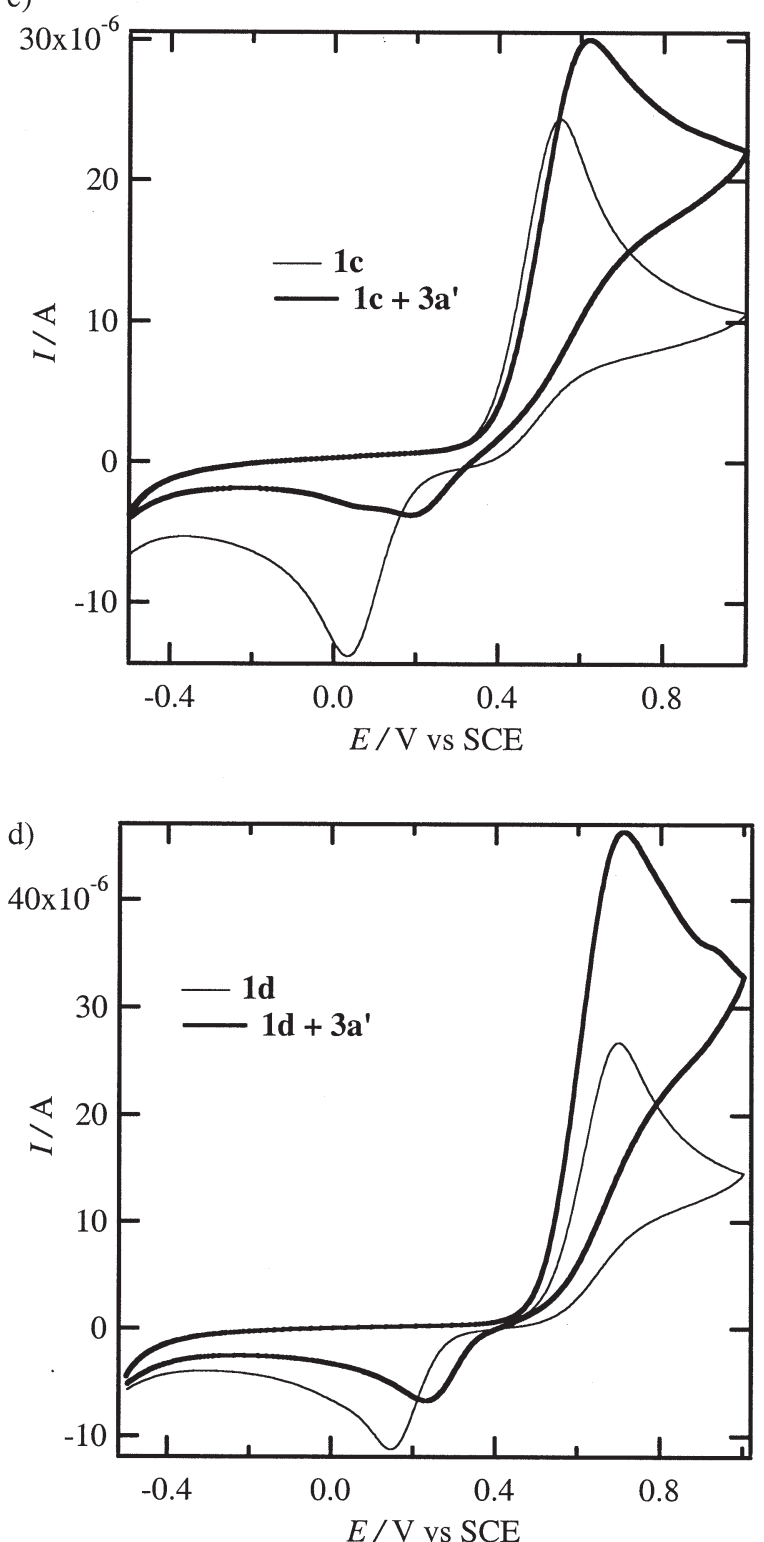

Figure 4. Cyclic voltammograms of the different hydroquinones 1a-d in the absence (thin line) and presence (bold line) of L-cysteine $3 \mathbf{a}^{\prime}$. Reprinted with permission from [68].

agreement with their electrochemical determinations [68]. The selectivity of hydroquinone probes $1 a-d$ toward L-cysteine was further confirmed by infusion of other nucleophilic amino acids (serine, threonine, lysine [68] ... and cysteine-free peptides and proteins [69]), which never gave any observable adducts. In this case again, 2-carboxymethylhydroquinone $\mathbf{1 d}$ proved to be the best candidate for on-line electrochemical tagging of cysteine. Once determined, the electrochemical properties of hydroquinones $\mathbf{1 a}-\mathbf{d}$ and the chemical kinetic constants of the addition of L-cysteine on electrochemically generated benzoquinones $\mathbf{2 a}-\mathbf{d}$, the influence of mass transport, labeling probe and target physical properties and microspray design on overall tagging efficiency were investigated by numerical simulations.

\section{Numerical Studies of Tagging Reactions}

A numerical model of the electrochemical tagging involving an electrolytic flow cell like the one used for the ESI experiments was developed. A comparison was done with the results obtained for the electrochemical tagging of $\beta$-lactoglobulin A with hydroquinone 1c [65]. This model was also used to correlate the on-line electrochemical tagging within the microspray experiments with the kinetics obtained by electrochemical studies [68]. The problem was described according to the literature [84, 85] by Scheme 2, where A, B, X, C, E represent, respectively, hydroquinones $\mathbf{1}$, benzoquinones 2 , labeling targets containing cysteine residues 3 , the formed adducts 4 , and the reoxidised adduct forms 5 . This corresponds 
(a)
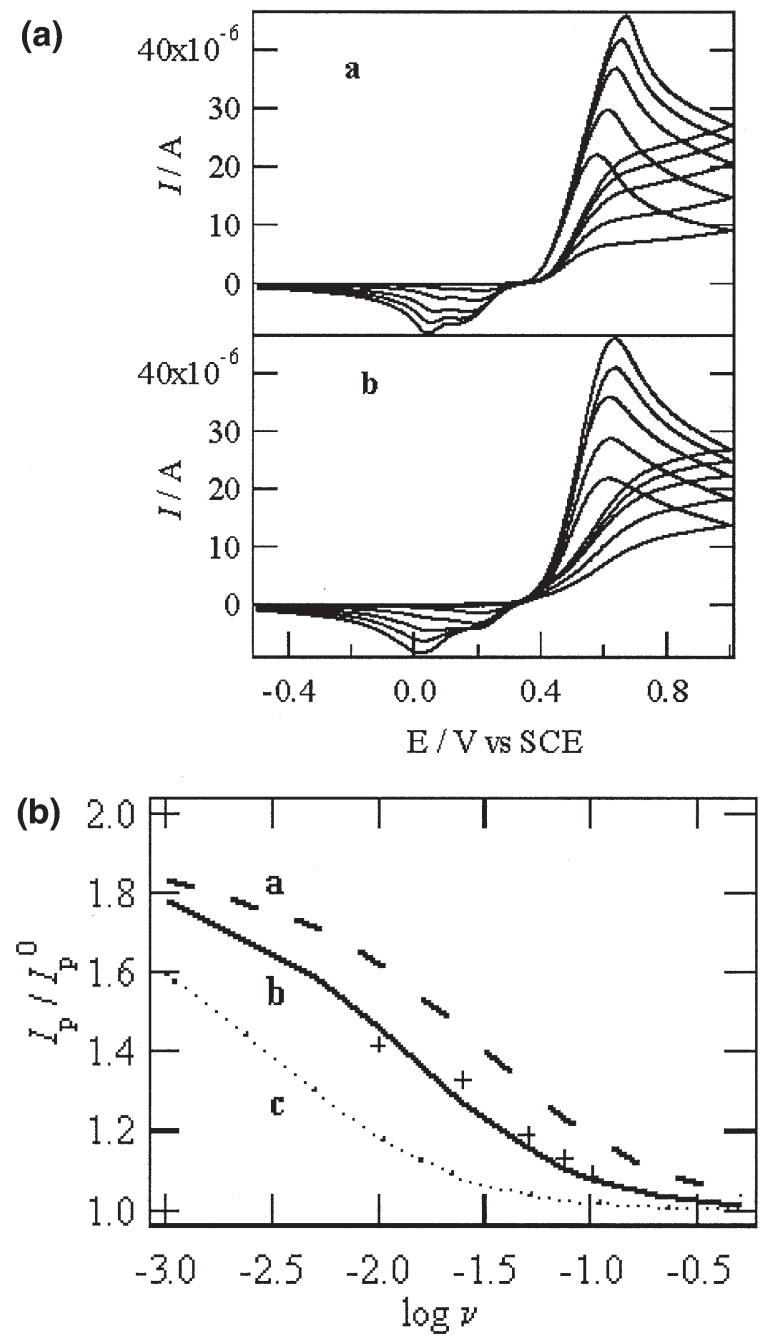

Figure 5. (a) Simulated (a) and experimental (b) voltammograms of hydroquinone $1 \mathbf{c}$ in the presence of L-cysteine $3 \mathbf{a}^{\prime}$. (b) Fitting of the simulated $I_{p} / I_{p}{ }^{0}$ curves to the experimental data for a: 500 $\mathrm{M}^{-1} \mathrm{~s}^{-1}, \mathrm{~b}: 210 \mathrm{M}^{-1} \mathrm{~S}^{-1}$, and c: $50 \mathrm{M}^{-1} \mathrm{~s}^{-1}$. Reprinted with permission from [66].

to an $\mathrm{EC}_{2 \mathrm{X}} \mathrm{E}$ mechanism where the homogeneous reaction (2) is characterized by the kinetic constant $k$. In this model, based on a microband electrode, the electrochemical reactions were assumed to be rapid (only limited by diffusion) due to the high overpotentials induced by the galvanostatic mode used for the experiments. They are also assumed to occur by a one-electron process. The kinetic constants of the two redox reactions (1) and (3) were maintained in a ratio $k_{o x} / k_{\text {red }}$ of 1000 in order to establish an oxidation regime at the electrode (Scheme 2).

The convection diffusion reaction (see eq 1 ) of the five species (A, B, X, C, E) was studied in a 2-D cross section geometry according to Figure 7 (for more details, see [67]).

$$
\frac{\partial c_{i}}{\partial t}+\operatorname{div}\left(-D_{i} \operatorname{grad} c_{i}+\mathbf{V} \cdot c_{i}\right)=R_{i}
$$

where $c_{i}$ is the concentration of specie $i, D_{i}$ is its diffusion coefficient, $\mathbf{V}$ is the fluid velocity and $R_{i}$ is the rate of generation or consumption of the specie $I$ following the kinetics of reactions (1-3). The finite element formulation, implemented on the Flux-Expert software [86], was first compared with the existing results from literature [67]. Many parameters such as the geometry of the microspray, the type of flow profile (such as a flat profile as in electro-osmotic flow or a parabolic profile as in hydrodynamic flow), the diffusion coefficient of the target $3(\mathrm{X})$ as well as the kinetic constant for the reaction between benzoquinone 2 (B) and target $3(X)$ were studied. As illustrated in Figure $8 \mathrm{a}$ for the experimental channel length $(x=7.9 \mathrm{~mm}$, i.e., 80 $x_{e}$ ), a relatively low rate constant such as $k=0.210$ $\mathrm{mM}^{-1} \mathrm{~s}^{-1}\left(210 \mathrm{M}^{-1} \mathrm{~s}^{-1}\right)$ [66] was high enough to obtain a significant tagging yield. For this low value of chemical rate, the microchannel should be long enough to provide a suitable residence time (here $t=2 \mathrm{~s}$ ) to let the species react before reaching the Taylor cone. For a shorter channel $\left(x=500 \mu \mathrm{m}\right.$, i.e., $\left.5 x_{e}\right)$, Figure $8 \mathrm{~b}$ describes the evolution of the concentration of the tagging products $\mathrm{C}$ and $\mathrm{E}$ (at the end of the channel) versus the rate constants $k$. For this low residence time value $(t=0.125 \mathrm{~s})$, a rate constant $k$ of $330 \mathrm{mM}^{-1} \mathrm{~s}^{-1}(3.3$ $10^{5} \mathrm{M}^{-1} \mathrm{~s}^{-1}$ ) is needed to obtain a tagging yield of $90 \%$.

To take into account the nature of the molecule to tag (i.e., L-cysteine, cysteine containing peptides and proteins), the influence of the diffusion coefficient of the target molecule $\mathrm{X}$ was studied. It was shown that a low diffusion coefficient value for $X$ does not affect the concentrations of the species A (hydroquinones), B (electrogenerated benzoquinones), or $\mathrm{C}+\mathrm{E}$ (adducts), because the target $X$ concentration is initially uniform. The only diffusion coefficient that plays an important role is the one of B (electrogenerated benzoquinones), because it is the only species that is generated in a boundary layer (which diffuses progressively from the electrode surface to the entire microchannel for sufficient residence times). Consequently, in the frame of the model assumptions, the resulting tagging yields are independent of the nature of the target biomolecule, especially if $\mathrm{A}$ and $\mathrm{B}$ are in relative high concentration toward $\mathrm{X}$ (i.e., $\mathrm{A} / \mathrm{X}$ ranging from 100 to 1000 in the experimental conditions).

Table 1. Kinetic constants of the addition of the different hydroquinones 1a-d on L-cysteine 3a' (see Scheme $\mathbf{1}$ for the position numbering)

\begin{tabular}{lccrc}
\hline Hydroquinone & 1a & 1b & 1c & 1d \\
\hline \hline Kinetic constant $k\left(\mathrm{M}^{-1} \mathrm{~s}^{-1}\right)$ & 50 & 50 & 210 & 5000 \\
Addition on position 2 (\%) & - & - & 25 & - \\
Addition on position 3 (\%) & $<2$ & $<2$ & 25 & 85 \\
Addition on position 5 (\%) & 47 & 26 & 25 & 2 \\
Addition on position 6 (\%) & 53 & 74 & 25 & 13 \\
\hline
\end{tabular}


a)

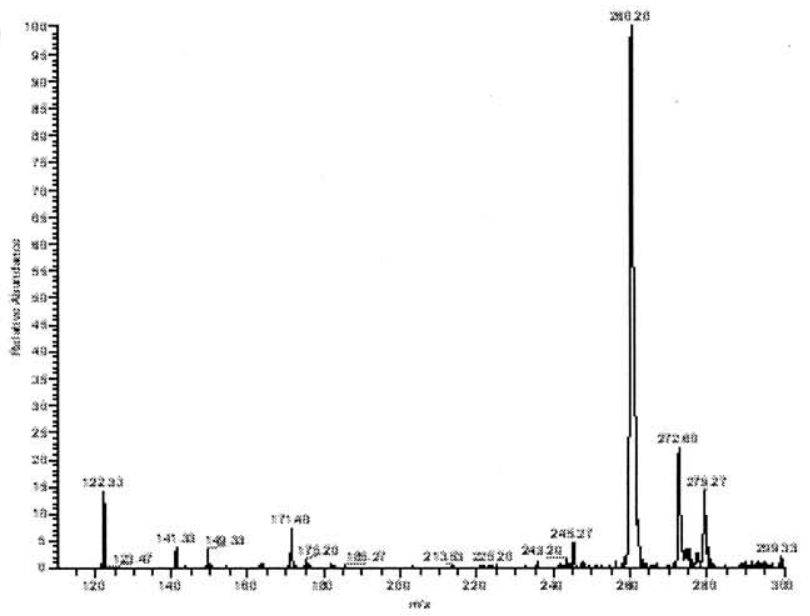

b)

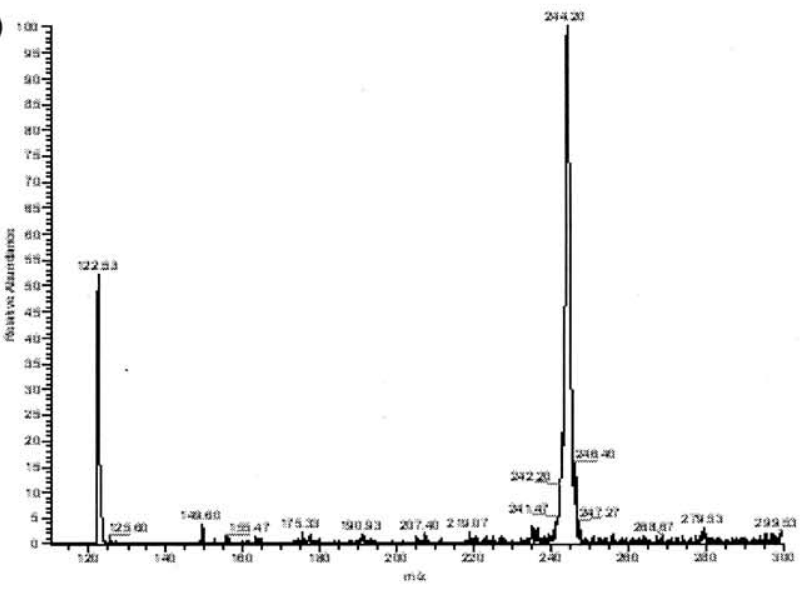

c)

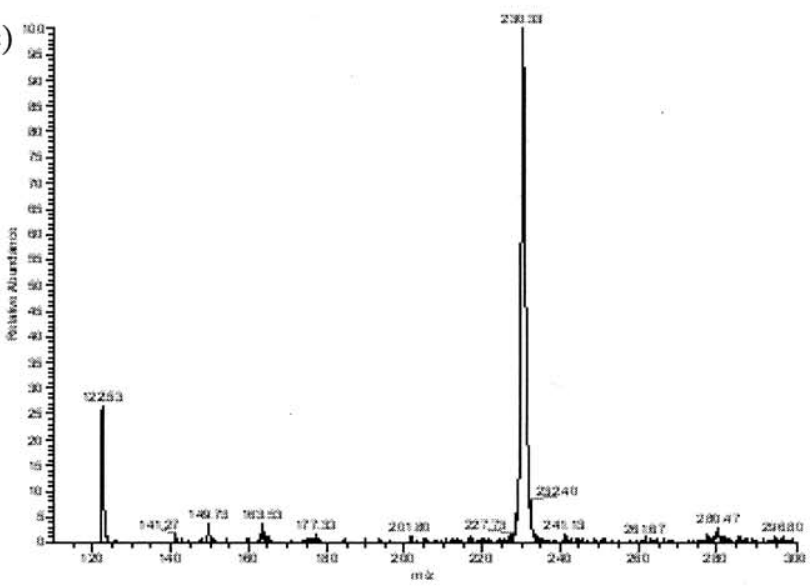

d)

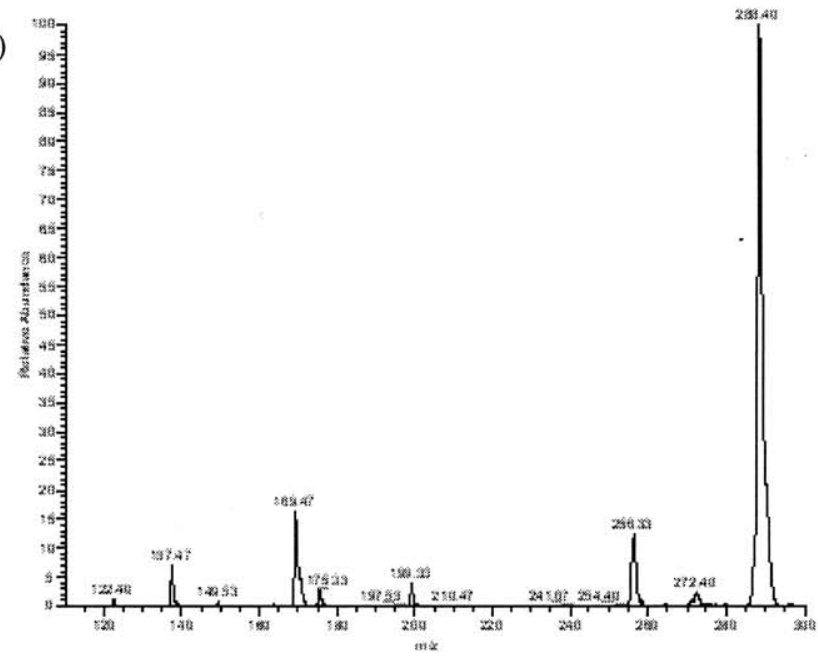

Figure 6. MS spectra of L-cysteine $3 \mathbf{a}^{\prime}$ delivered to the mass spectrometer through the polymer microspray in the presence of the different hydroquinones: (a) 2-methoxyhydroquinone 1a, (b) 2-methylhydroquinone $\mathbf{1 b}$, (c) hydroquinone 1c, (d) 2-carboxymethylhydroquinone 1d. Reprinted with permission from [68].

\section{On-Line Tagging of Peptides and Application to Protein Identification}

The first direct application of the on-line electrochemical tagging was to directly count the number of cysteine

Table 2. Tagging yields of the different hydroquinones 1a-d on L-cysteine $\mathbf{3} \mathbf{a}^{\prime}$, peptide $\mathbf{3} \mathbf{b}^{\prime}$ and protein $\mathbf{3 g ^ { \prime }}$ as measured from the mass spectra

\begin{tabular}{lcccc}
\hline Hydroquinone & 1a & 1b & 1c & 1d \\
\hline \hline $\begin{array}{l}\text { MS tagging yield of } \\
\text { L-Cysteine 3a' }\end{array}$ & $87 \%$ & $63 \%$ & $76 \%$ & $99 \%$ \\
$\begin{array}{l}\text { MS tagging yield of } \\
\text { peptide } \mathbf{3 b}^{\prime 2}\end{array}$ & $55 \%$ & $24 \%$ & $22 \%$ & $56 \%$ \\
$\begin{array}{l}\text { MS tagging yield of } \\
\quad \beta \text {-lactoglobulin A } \mathbf{3 g}^{\prime 3}\end{array}$ & 27 to $52 \%{ }^{4}$ & $26 \%$ & $23 \%$ & $31 \%$ \\
\hline
\end{tabular}

${ }^{1}$ Ratio hydroquinones 1a-d/L-cysteine $3 \mathbf{a}^{\prime}: 20 \mathrm{mM} / 0.2 \mathrm{mM}$, from [68]. ${ }^{2}$ Ratio hydroquinones 1a-d/peptide $3 \mathbf{b}^{\prime}$ : $20 \mathrm{mM} / 50 \mu \mathrm{M}$, from [69].

${ }^{3}$ Ratio hydroquinones 1a-d/ $\beta$-lactoglobulin $\mathbf{A} \mathbf{3 g}$ ': $5 \mathrm{mM} / 5 \mu \mathrm{M}$, from [68].

${ }^{4}$ The tagging yield was found to increase from 27 to $52 \%$ in 80 minutes of infusion. residues within a given peptide. Several synthetic peptides (from 6 to 11 amino acids long) containing up to three cysteines were infused together with hydroquinones $\mathbf{1 a}-\mathbf{d}$ and the resulting adducts analyzed by mass spectrometry. For peptides containing one and two cysteines, clear adduct peaks were identified in the

$$
\begin{aligned}
& \mathrm{A} \frac{k_{\text {oxl }}}{k_{\text {redl }}} \mathrm{B}+\mathrm{e}^{-} \\
& \mathrm{B}+\mathrm{X} \longrightarrow \mathrm{k} \\
& \mathrm{C} \frac{k_{o x 2}}{k_{r e d 2}} \mathrm{E}+\mathrm{e}^{-}
\end{aligned}
$$

Scheme 2. Definition of the electrochemical-chemical-electrochemical reactions implemented in the numerical model (A are the hydroquinones $1, \mathrm{~B}$ the electrogenerated benzoquinones $2, \mathrm{X}$ the label target 3, $\mathrm{C}$ the adduct, and $\mathrm{E}$ the oxidized adduct). 


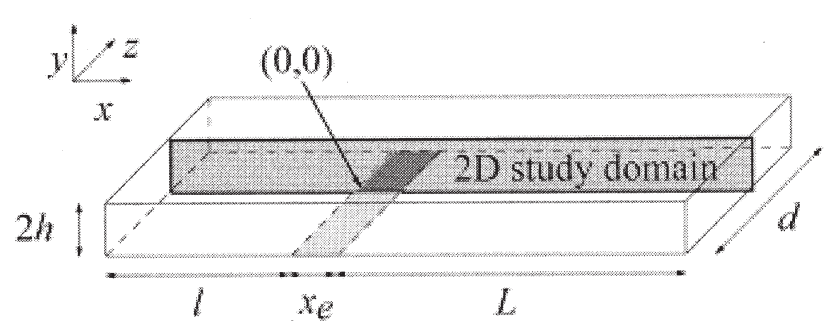

Figure 7. Definition of the 2-D geometry used for the numerical simulations. Reprinted with permission from [67].

mass spectrum, the number of which corresponds exactly to the number of cysteines in the analyzed peptides only with 2-carboxymethylhydroquinone 1d [69, 87]. In the most challenging experiment, the peptide $3 \mathbf{e}^{\prime}$ (KCTCCA) which contains three cysteine residues (two of which are consecutive) gave clearly identifiable adduct peaks only when labeled with hydroquinone $\mathbf{1 d}$, as shown in Figure 9. Hydroquinone 1c, for example, did not prove a tagging of all cysteine residues. One striking observation is the decrease of the apparent tagging yields obtained with $\mathbf{1 d}$ when switching from L-cysteine $(99 \%)$ to peptides $(56 \%)$ and proteins $(31 \%$, as measured from spectra in Figure 10), as shown in Table 2. One possible explanation could be steric hindrance, as surrounding amino acids in peptides can alter the general accessibility and reactivity of cysteines; the case is even worse for proteins, where structural features (such as hydrophobic pockets) can still be present in organic solvents at low $\mathrm{pH}$, as is the case for $\beta$-lactoglobulin A [88, 89], thus reducing the probe accessibility to specific amino acid residues. Nevertheless, it can also be hypothesized that these differences in apparent tagging yields may originate from kinetic limitations: all on-line tagging experiments were performed with an electrospray current around $120 \mathrm{nA}$, meaning that the concentration of electrogenerated benzoquinones on the microelectrode was the same, whereas the concentration of the target varied from $200 \mu \mathrm{M}$ (for L-cysteine) down to $50 \mu \mathrm{M}$ (for experiments on peptides) and 5 $\mu \mathrm{M}$. It is thus possible that the tagging yield observed at the end of the microchannel was dictated by kinetic limitations only. This last point has still to be confirmed by further experimental investigations.

After the demonstration of an efficient tagging on cysteine containing peptides, the obvious further step was to evaluate the potential of the mass tagging technology for protein identification through peptide mass fingerprinting. To confirm that the newly developed mass tagging methodology is relevant to protein identification through peptide mass fingerprinting, a model experiment was designed with purified proteins: the protein was first chemically reduced and digested by trypsin; the resulting peptides were separated by RP-HPLC at high flow rate and fractions were collected. 2-carboxymethylhydroquinone $1 \mathbf{d}$ was then added to the fractions prior to delivery to the mass spectrometer through the polymer microspray. Both untagged and tagged peptide masses were acquired. SwissProt database was then searched using whether Mascott (http:/ / www.matrixscience.com/) [90], with or without the specification of the number of cysteine residues per peptide read directly from MS spectra. For a model protein possessing a large number of cysteines such as bovine serum albumin (BSA), a Mascott score of 81 (the uncertainty threshold being 66) and a protein sequence coverage of $74 \%$ were obtained without information on cysteine content. When the number of cysteine is specified for each tryptic peptide containing some cysteine residues, the score rises to 206, thus showing the potential of the mass tagging approach for protein identification through peptide mass fingerprinting [69].
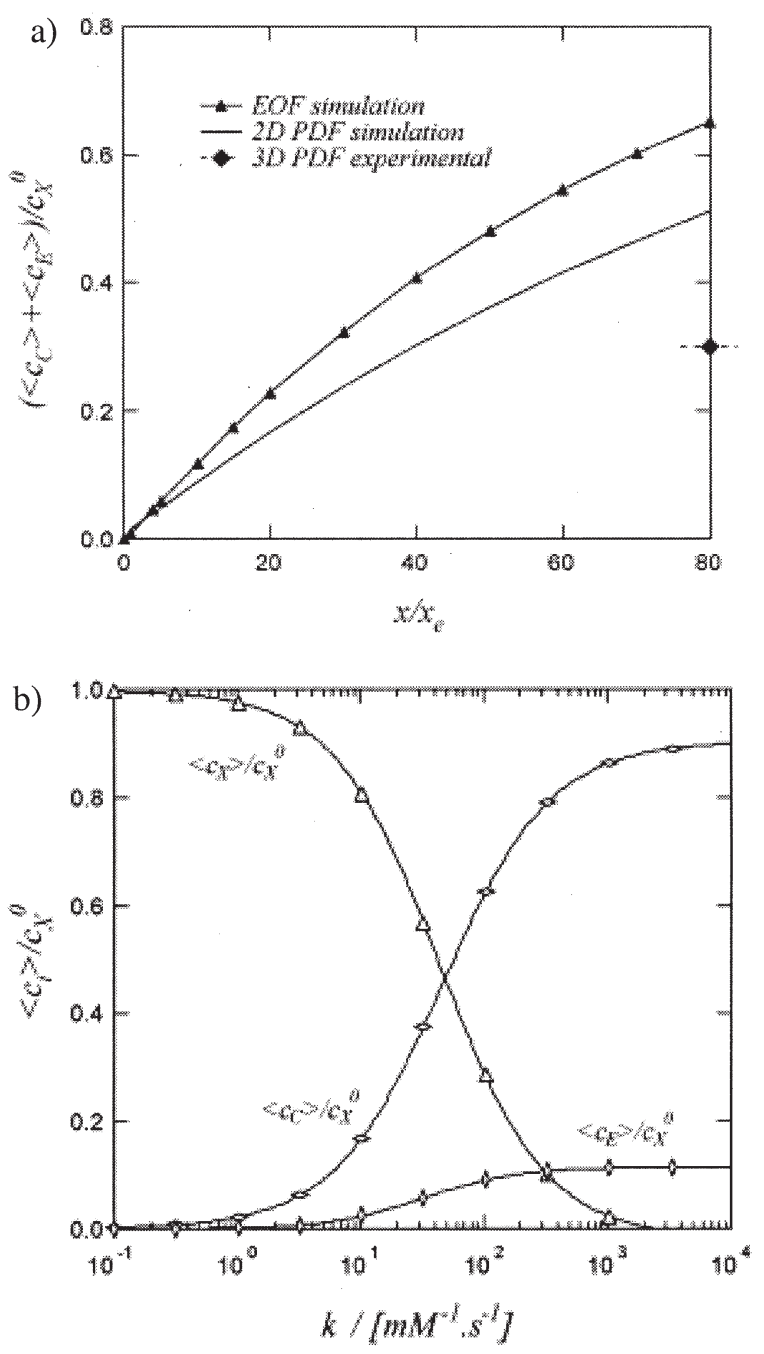

Figure 8. (a) Influence of the channel length compared to the microband electrode length on the tagging yield (at a fixed microspray length of $x=7.9 \mathrm{~mm}$ ), for simulated electro-osmotic flow (EOF) or pressure driven flow (PDF). (b) Dependency of the concentrations of targets $\mathrm{X}$, formed adducts $\mathrm{C}$, and reoxidized products $\mathrm{E}$ versus the homogenous rate constant $k$, for a short microspray $(x=500 \mu \mathrm{m})$. Reprinted with permission from [67]. 

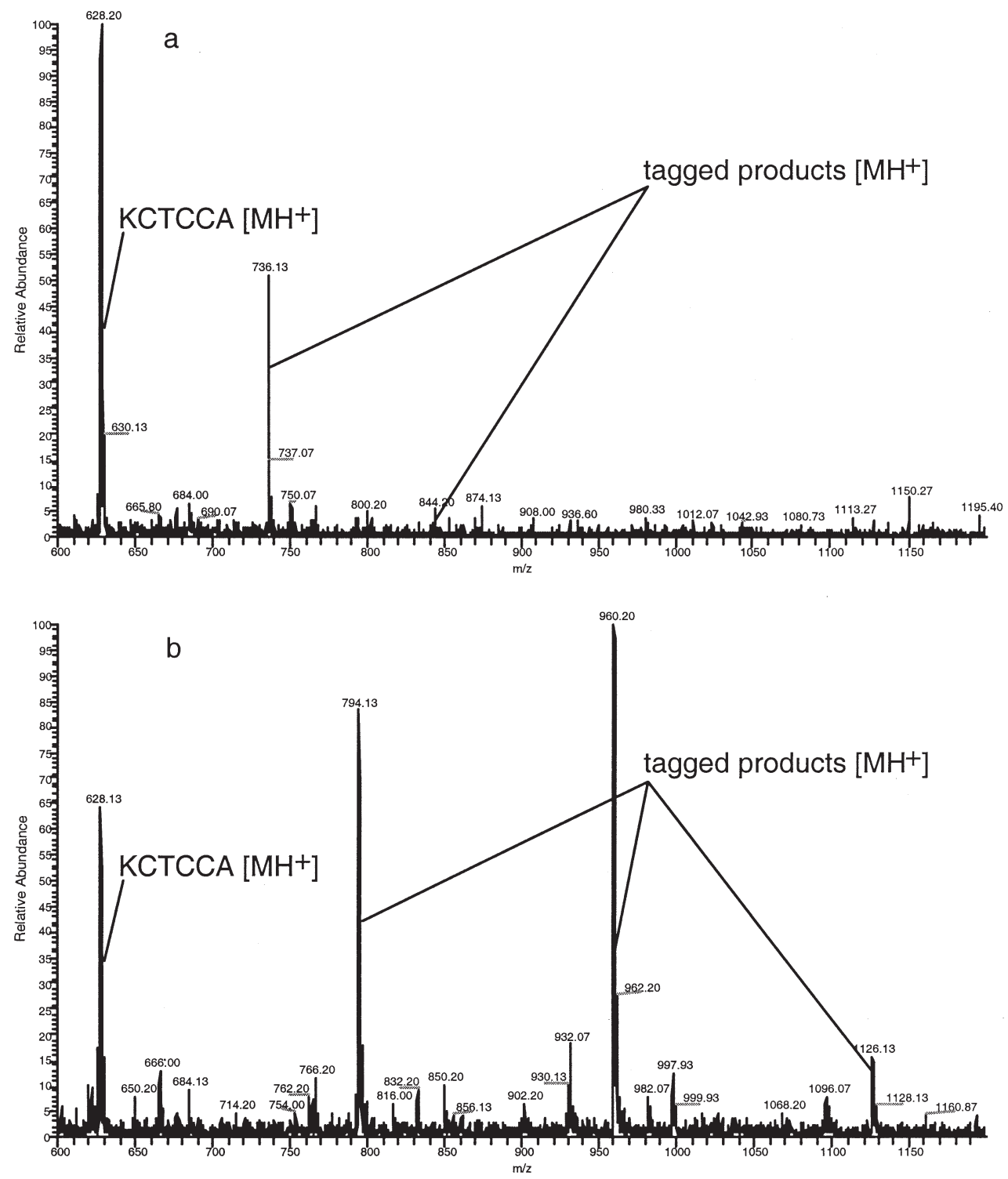

Figure 9. MS spectra obtained for the infusion of peptide $3 \mathbf{e}^{\prime}$ (KCTCCA) with the different hydroquinones 1c (a) and 1d (b). Reprinted with permission from [87].

\section{Future Direction of Works}

First, further validation of the on-line mass tagging of cysteine residues is needed to fully evaluate the technology for protein identification, namely, its use for simple protein mixtures. To push the technology a step further (i.e., to the analysis of more complex protein mixtures) it will be necessary to investigate the effect of the benzoquinone tag on the fragmentation behavior of labeled peptides. Moreover, refined strategies for the data selective automated fragmentation of peptides during LC runs of tryptic peptides will be needed, to exploit the full potential of the mass tag technology in conjunction with peptide sequence acquisition. Possible new directions include the development of additional electrochemical probes, specific for other amino acids or for particular groups (for example, phosphorylated amino acids after elimination of the phosphate group). Complementarily, quantitative mass tags would be interesting in the field of quantitative proteomics at the protein level. One could then envision the differential analysis of two different samples through the use of microfabricated dual microsprays.

\section{Conclusions}

We have shown herein the potential use of the inherent electrochemistry of electrospray for the generation of cysteine-specific probes for mass tagging of peptides and proteins. After a thorough investigation of the electrochemistry and chemistry of tagging reactions, numerical simulations were performed to characterize the influence 

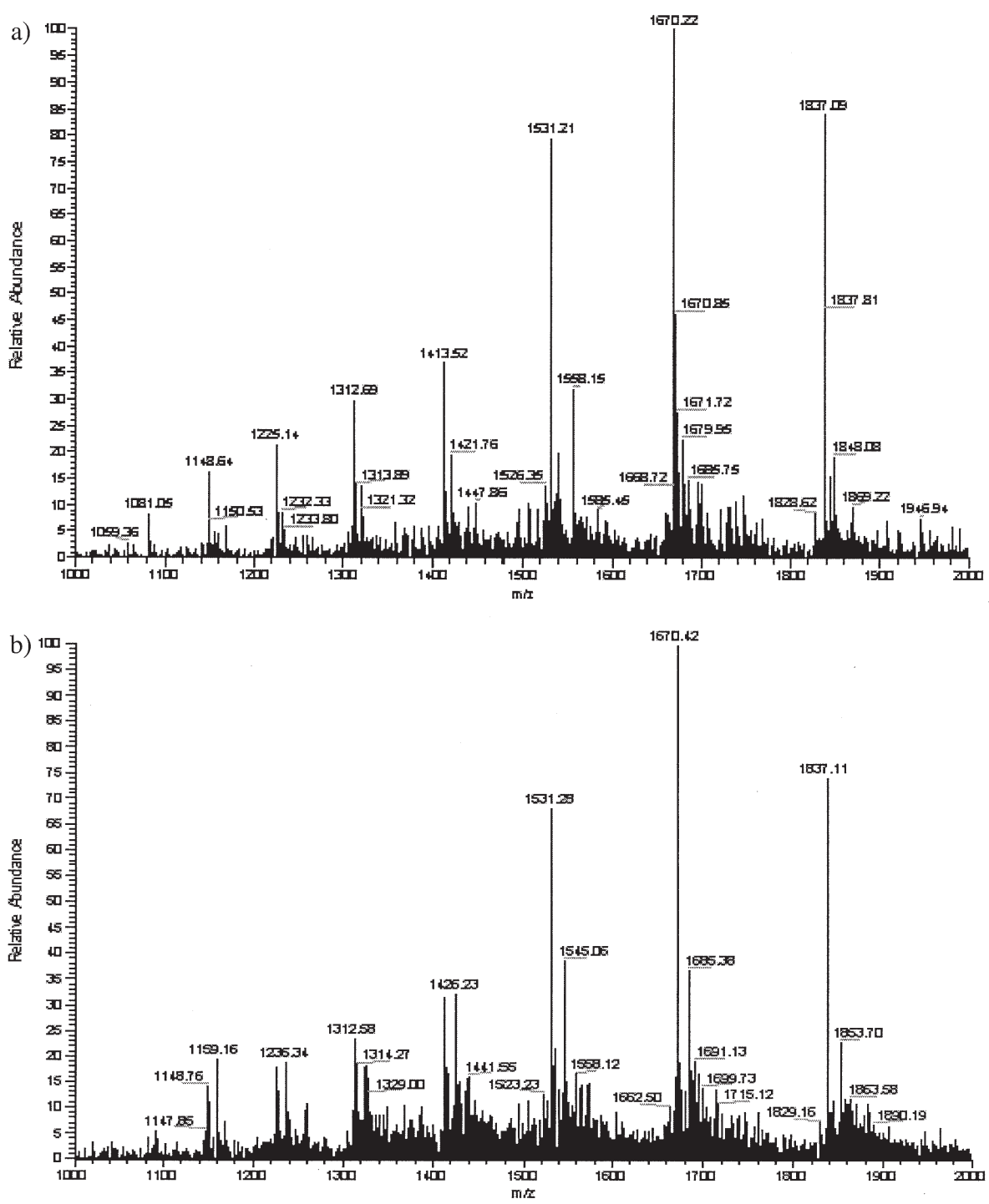

Figure 10. Electrochemical tagging of $\beta$-lactoglobulin A with (a) hydroquinone 1c and (b) 2-carboxymethylhydroquinone $\mathbf{1 d}$ in degassed conditions. Reprinted with permission from [68].

of the electrochemical flow cell (constituted by the microspray microchannel) size and homogeneous reaction kinetics on the tagging efficiency. Finally, potential application of this new technology to protein identification through peptide mass fingerprinting was presented. Besides this particular application, our approach shows the interest of microfabricated electrochemical flow cells to hyphen electrochemistry with mass spectrometry. Unlike commercial electrochemical cells, microfabricated cells can be easily prototyped and their design adapted to a particular application. Moreover, the use of micro dimensions allows to properly control the mass transport phenomena and electrochemical reactions above microelectrode surfaces.

\section{Acknowledgments}

The Fonds National Suisse pour la Recherche Scientifique, l'Ecole Polytechnique Fédérale de Lausanne, the European
Union (5th Research Framework Program, project MicroProteoMicS) are acknowledged for financial support. The authors thank André Fattet (Mechanical Workshop, Institute for Chemical Engineering and Sciences, EPFL), Alain Razaname (Laboratory of Nucleic Acid Chemistry, EPFL), Peter Pechy (Laboratory for Photonics and Interfaces, EPFL), Eugen Damoc (Laboratory of Analytical Chemistry and Biopolymer Structure Analysis, Konstanz University, Germany) for technical support, and Manfred Heller (Department of Clinical Research, Medical Faculty of the University of Bern, Switzerland) for helpful discussions.

\section{References}

1. Reyes, D. R.; Iossifidis, D.; Auroux, P. A.; Manz, A. Micro total analysis systems. 1. Introduction, theory, and technology. Anal. Chem. 2002, 74, 2623-2636.

2. Auroux, P. A.; Iossifidis, D.; Reyes, D. R.; Manz, A. Micro total analysis systems. 2. Analytical standard operations and applications. Anal. Chem. 2002, 74, 2637-2652. 
3. Jacobson, S. C.; Culbertson, C. T.; Daler, J. E.; Ramsey, J. M. Microchip structures for submillisecond electrophoresis. Anal. Chem. 1998, 70, 3476-3480.

4. Bai, X.; Roussel, C.; Jensen, H.; Girault, H. H. Polyelectrolytemodified short microchannel for cation separation. Electrophoresis 2004, 25, 931-935.

5. Ramsey, J. D.; Jacobson, S. C.; Culbertson, C. T.; Ramsey, J. M. High-efficiency, two-dimensional separations of protein digests on microfluidic devices. Anal. Chem. 2003, 75, 3758-3764.

6. Clicq, D.; Vervoort, N.; Vounckx, R.; Ottevaere, H.; Buijs, J.; Gooijer, C.; Ariese, F.; Baron, G. V.; Desmet, G. Sub-second liquid chromatographic separations by means of shear-driven chromatography. J. Chromatogr. A 2002, 979, 33-42.

7. Rossier, J. S.; Roberts, M. A.; Ferrigno, R.; Girault, H. H. Electrochemical detection in polymer microchannels. Anal. Chem. 1999, 71, 4294-4299.

8. Rossier, J. S.; Girault, H. H. Enzyme linked immunosorbent assay on a microchip with electrochemical detection. Lab Chip 2001, 1, 153-157.

9. Peterson, D. S.; Rohr, T.; Svec, F.; Frechet, J. M. J. Enzymatic microreactor-on-a-chip: Protein mapping using trypsin immobilized on porous polymer monoliths molded in channels of microfluidic devices. Anal. Chem. 2002, 74, 4081-4088.

10. Figeys, D.; Pinto, D. Proteomics on a chip: Promising developments. Electrophoresis 2001, 22, 208-216.

11. Lion, N.; Rohner, T. C.; Dayon, L.; Arnaud, I. L.; Damoc, E.; Youhnovski, N.; Wu, Z. Y.; Roussel, C.; Josserand, J.; Jensen, H.; Rossier, J. S.; Przybylski, M.; Girault, H. H. Microfluidic systems in proteomics. Electrophoresis 2003, 24, 3533-3562.

12. Lion, N.; Reymond, F.; Girault, H. H.; Rossier, J. S. Why the move to microfluidics for protein analysis? Curr. Opin. Biotech. 2004, 15, 31-37.

13. Ramsey, R. S.; Ramsey, J. M. Generating electrospray from microchip devices using electroosmotic pumping. Anal. Chem. 1997, 69, 1174-1178.

14. Xue, Q. F.; Dunayevskiy, Y. M.; Foret, F.; Karger, B. L. Integrated multichannel microchip electrospray ionization mass spectrometry: Analysis of peptides from on-chip tryptic digestion of melittin. Rapid Commun. Mass Spectrom. 1997, 11, 1253-1256.

15. Deng, Y.; Henion, J.; Li, J.; Thibault, P.; Wang, C.; Harrison, D. J. Chip-based capillary electrophoresis/mass spectrometry determination of carnitines in human urine. Anal. Chem. 2001, 73, 639-646.

16. Kim, J. S.; Knapp, D. R. Microfabricated PDMS multichannel emitter for electrospray ionization mass spectrometry. J. Am. Soc. Mass Spectrom. 2001, 12, 463-469.

17. Rohner, T. C.; Rossier, J. S.; Girault, H. H. Polymer microspray with an integrated thick-film microelectrode. Anal. Chem. 2001, $73,5353-5357$.

18. Gobry, V.; van Oostrum, J.; Martinelli, M.; Rohner, T.; Rossier, J. S.; Girault, H. H. Microfabricated polymer injector for direct mass spectrometry coupling. Proteomics 2002, 2, 405-412.

19. Rossier, J. S.; Youhnovski, N.; Lion, N.; Damoc, E.; Reymond, F.; Girault, H. H.; Przybylski, M. Thin-chip microspray system for coupling with high performance Fourier-Transform Ion Cyclotron Resonance mass spectrometry. Angew. Chem. Intl. Ed. 2003, 42, 53-58.

20. Oleschuk, R. D.; Harrison, D. J. Analytical microdevices for mass spectrometry. Trac-Trends Anal. Chem. 2000, 19, 379-388.

21. Schultz, G. A.; Corso, T. N.; Prosser, S. J.; Zhang, S. A fully integrated monolithic microchip electrospray device for mass spectrometry. Anal. Chem. 2000, 72, 4058-4063.

22. Lion, N.; Gobry, V.; Jensen, H.; Rossier, J.; Girault, H. H. Integration of a membrane-based desalting in a microfabricated disposable polymer injector for mass spectrometric protein analysis. Electrophoresis 2002, 23, 3583-3588.
23. Lion, N.; Gellon, J. O.; Jensen, H.; Girault, H. H. On-chip protein sample desalting and preparation for direct-coupling with electrospray ionization mass spectrometry. J. Chromatogr. A 2003, 1003, 11-19.

24. Wachs, T.; Henion, J. A device for automated direct sampling and quantitation from solid-phase sorbent extraction cards by electrospray tandem mass spectrometry. Anal. Chem. 2003, 75, $1769-1775$.

25. Li, J.; Kelly, J. F.; Chernushevich, I.; Harrison, D. J.; Thibault, P. Separation and identification of peptides from gel-isolated membrane proteins using a microfabricated device for combined capillary electrophoresis/nanoelectrospray mass spectrometry. Anal. Chem. 2000, 72, 599-609.

26. Li, J. J.; Thibault, P.; Bings, N. H.; Skinner, C. D.; Wang, C.; Colyer, C.; Harrison, J. Integration of microfabricated devices to capillary electrophoresis-electrospray mass spectrometry using a low dead volume connection: Application to rapid analyses of proteolytic digests. Anal. Chem. 1999, 71, 3036-3045.

27. Kameoka, J.; Craighead, H. G.; Zhang, H. W.; Henion, J. A polymeric microfluidic chip for CE/MS determination of small molecules. Anal. Chem. 2001, 73, 1935-1941.

28. Lazar, I. M.; Ramsey, R. S.; Ramsey, J. M. On-chip proteolytic digestion and analysis using "wrong-way- round" electrospray time-of-flight mass spectrometry. Anal. Chem. 2001, 73, 1733-1739.

29. Li, J. J.; LeRiche, T.; Tremblay, T. L.; Wang, C.; Bonneil, E.; Harrison, D. J.; Thibault, P. Application of microfluidic devices to proteomics research-Identification of trace-level protein digests and affinity capture of target peptides. Mol. Cell. Proteomics 2002, 1, 157-168.

30. Blades, A. T.; Ikonomou, M. G.; Kebarle, P. Mechanism of Electrospray Mass-Spectrometry-Electrospray as an Electrolysis Cell. Anal. Chem. 1991, 63, 2109-2114.

31. Van Berkel, G. J.; Zhou, F. M. Characterization of an electrospray ion-source as a controlled-current electrolytic cell. Anal. Chem. 1995, 67, 2916-2923.

32. Van Berkel, G. J.; Zhou, F. M.; Aronson, J. T. Changes in bulk solution $\mathrm{pH}$ caused by the inherent controlled-current electrolytic process of an electrospray ion source. Int. J. Mass Spectrom. Ion Processes 1997, 162, 55-67.

33. Zhou, S. L.; Edwards, A. G.; Cook, K. D.; Van Berkel, G. J. Investigation of the electrospray plume by laser-induced fluorescence spectroscopy. Anal. Chem. 1999, 71, 769-776.

34. Van Berkel, G. J.; Giles, G. E.; Bullock, J. S.; Gray, L. J. Computational simulation of redox reactions within a metal electrospray emitter. Anal. Chem. 1999, 71, 5288-5296.

35. de la Mora, J. F.; Van Berkel, G. J.; Enke, C. G.; Cole, R. B.; Martinez-Sanchez, M.; Fenn, J. B. Electrochemical processes in electrospray ionization mass spectrometry-Discussion. J. Mass Spectrom. 2000, 35, 939-952.

36. Van Berkel, G. J. Electrolytic deposition of metals on to the high-voltage contact in an electrospray emitter: implications for gas-phase ion formation. J. Mass Spectrom. 2000, 35, 773-783.

37. Van Berkel, G. J. Insights into analyte electrolysis in an electrospray emitter from chronopotentiometry experiments and mass transport calculations. J. Am. Soc. Mass Spectrom. 2000, 11, 951-960.

38. Van Berkel, G. J.; Kertesz, V. Redox buffering in an electrospray ion source using a copper capillary emitter. J. Mass Spectrom. 2001, 36, 1125-1132.

39. Kertesz, V.; Van Berkel, G. J. Minimizing analyte electrolysis in an electrospray emitter. J. Mass Spectrom. 2001, 36, 204-210.

40. Van Berkel, G. J.; Asano, K. G.; Schnier, P. D. Electrochemical processes in a wire-in-a-capillary bulk-loaded, nano-electrospray emitter. J. Am. Soc. Mass Spectrom. 2001, 12, 853-862. 
41. Rohner, T. C.; Lion, N.; Girault, H. H. Electrochemical and theoretical aspects of electrospray ionization. Phys. Chem. Chem. Phys. 2004, 6, 3056-3068.

42. Van Berkel, G. J. Modeling of inherent electrochemical processes in electrospray. J. Am. Soc. Mass Spectrom. 2004, in this issue.

43. Zhou, F. M.; Van Berkel, G. J. Electrochemistry combined online with electrospray mass-spectrometry. Anal. Chem. 1995, 67, 3643-3649.

44. Deng, H. T.; Van Berkel, G. J. A thin-layer electrochemical flow cell coupled on-line with electrospray-mass spectrometry for the study of biological redox reactions. Electroanalysis 1999, 11, 857-865.

45. Van Berkel, G. J.; Asano, K. G.; Kertesz, V. Enhanced study and control of analyte oxidation in electrospray using a thin-channel, planar electrode emitter. Anal. Chem. 2002, 74, 5047-5056.

46. Van Berkel, G. J.; Asano, K. G.; Granger, M. C. Controlling analyte electrochemistry in an electrospray ion source with a three-electrode emitter cell. Anal. Chem. 2004, 76, 1493-1499.

47. Van Berkel, G. J.; Quirke, J. M. E.; Tigani, R. A.; Dilley, A. S.; Covey, T. R. Derivatization for electrospray ionization mass spectrometry. 3. Electrochemically ionizable derivatives. Anal. Chem. 1998, 70, 1544-1554.

48. Quirke, J. M. E.; Hsu, Y. L.; Van Berkel, G. J. Ferrocene-based electroactive derivatizing reagents for the rapid selective screening of alcohols and phenols in natural product mixtures using electrospray-tandem mass spectrometry. J. Nat. Prod. 2000, 63, 230-237.

49. Van Berkel, G. J.; Quirke, J. M. E.; Adams, C. L. Derivatization for electrospray ionization-mass spectrometry. 4. Alkenes and alkynes. Rapid Commun. Mass Spectrom. 2000, 14, 849-858.

50. Quirke, J. M. E.; Van Berkel, G. J. Electrospray tandem mass spectrometric study of ferrocene carbamate ester derivatives of saturated primary, secondary, and tertiary alcohols. J. Mass Spectrom. 2001, 36, 179-187.

51. Quirke, J. M. E.; Hsu, Y. L.; Van Berkel, G. J. Selective detection of derivatized alcohols and phenols in essential oils by electrospray-tandem mass spectrometry. J. Essent. Oil Res. 2001, 13, 324-331.

52. Bruins, A. P. Biological applications of electrochemistry/mass spectrometry. J. Am. Soc. Mass Spec. 2004, in this issue.

53. Jurva, U.; Wikstrom, H. V.; Bruins, A. P. In vitro mimicry of metabolic oxidation reactions by electrochemistry/mass spectrometry. Rapid Commun. Mass Spectrom. 2000, 14, 529-533.

54. Jurva, U.; Wikstrom, H. V.; Weidolf, L.; Bruins, A. P. Comparison between electrochemistry/mass spectrometry and cytochrome P450 catalyzed oxidation reactions. Rapid Commun. Mass Spectrom. 2003, 17, 800-810.

55. Diehl, G.; Karst, U. On-line electrochemistry-MS and related techniques. Anal. Bioanal. Chem. 2002, 373, 390-398.

56. Karst, U. Electrochemistry/mass spectrometry (EC/MS)-A new tool to study drug metabolism and reaction mechanisms. Angew. Chem. Intl. Ed. 2004, 43, 2476-2478

57. Brancia, F. L.; Butt, A.; Beynon, R. J.; Hubbard, S. J.; Gaskell, S. J.; Oliver, S. G. A combination of chemical derivatisation and improved bioinformatic tools optimises protein identification for proteomics. Electrophoresis 2001, 22, 552-559.

58. Sechi, S.; Chait, B. T. Modification of cysteine residues by alkylation. A tool in peptide mapping and protein identification. Anal. Chem. 1998, 70, 5150-5158.

59. Regnier, F. E.; Riggs, L.; Zhang, R. J.; Xiong, L.; Liu, P. R.; Chakraborty, A.; Seeley, E.; Sioma, C.; Thompson, R. A. Comparative proteomics based on stable isotope labeling and affinity selection. J. Mass spectrom. 2002, 37, 133-145.

60. Giovanelli, D.; Lawrence, N. S.; Jiang, L.; Jones, T. G. J.; Compton, R. G. Electrochemical characterization of sulfide tagging via its reaction with benzoquinone derivatives. Anal. Lett. 2003, 36, 2941-2959.

61. Lawrence, N. S.; Davis, J.; Compton, R. G. Analytical strategies for the detection of sulfide: a review. Talanta 2000, 52, 771-784.

62. White, P. C.; Lawrence, N. S.; Davis, J.; Compton, R. G. Electrochemically initiated 1,4 additions: A versatile route to the determination of thiols. Anal. Chim. Acta 2001, 447, 1-10.

63. Hignett, G.; Threlfell, S.; Wain, A. J.; Lawrence, N. S.; Wilkins, S. J.; Davis, J.; Compton, R. G.; Cardosi, M. F. Electroanalytical exploitation of quinone-thiol interactions: application to the selective determination of cysteine. Analyst 2001, 126, 353-357.

64. White, P. C. Lawrence, N. S. Tsai, Y. C. Davis, J. Compton, R. G. Electrochemically driven derivatisation-detection of cysteine. Mikrochim. Acta 2001, 137, 87-91

65. Rohner, T. C.; Rossier, J. S.; Girault, H. H. On-line electrochemical tagging of cysteines in proteins during nanospray. Electrochem. Commun. 2002, 4, 695-700.

66. Roussel, C.; Rohner, T. C.; Jensen, H.; Girault, H. H. Mechanistic aspects of on-line electrochemical tagging of free $\mathrm{L}$ cysteine residues during electrospray ionisation for mass spectrometry in protein analysis. Chem. Phys. Chem. 2003, 4, 200-206.

67. Rohner, T. C.; Josserand, J.; Jensen, H.; Girault, H. H. Numerical investigation of an electrochemically induced tagging in a nanospray for protein analysis. Anal. Chem. 2003, 75, 2065-2074.

68. Roussel, C.; Dayon, L.; Jensen, H.; Girault, H. H. On-line cysteine modification for protein analysis: new probes for electrochemical tagging nanospray mass spectrometry. J. Electroanal. Chem. 2004, 570, 187-199.

69. Dayon, L.; Roussel, C.; Prudent, M.; Lion, N.; Girault, H. H. On-line counting of cysteine residues in peptides during electrospray ionisation by electrogenerated tags and its application to protein identification. Electrophoresis, in press.

70. do Lago, C. L.; da Silva, H. D. T.; Neves, C. A.; Brito-Neto, J. G. A.; da Silva, J. A. F. A dry process for production of microfluidic devices based on the lamination of laser-printed polyester films. Anal. Chem. 2003, 75, 3853-3858.

71. Becker, H.; Gartner, C. Polymer microfabrication methods for microfluidic analytical applications. Electrophoresis 2000, 21, $12-26$.

72. Johnson, T. J.; Waddell, E. A.; Kramer, G. W.; Locascio, L. E. Chemical mapping of hot-embossed and UV-laser- ablated microchannels in poly(methyl methacrylate) using carboxylate specific fluorescent probes. Appl. Surf. Sci. 2001, 181, 149-159.

73. Pugmire, D. L.; Waddell, E. A.; Haasch, R.; Tarlov, M. J.; Locascio, E. Surface characterization of laser-ablated polymers used for microfluidics. Anal. Chem. 2002, 74, 871-878.

74. Wagner, F.; Hoffmann, P. Novel structure formation in poly(ethylene therephthalate) by scanning excimer laser ablation. Appl. Surf. Sci. 2000, 154, 627-632.

75. Becker, H.; Locascio, L. E. Polymer microfluidic devices. Talanta 2002, 56, 267-287.

76. Roberts, M. A.; Rossier, J. S.; Bercier, P.; Girault, H. UV laser machined polymer substrates for the development of microdiagnostic systems. Anal. Chem. 1997, 69, 2035-2042.

77. Schwarz, A.; Rossier, J. S.; Roulet, E.; Mermod, N.; Roberts, M. A.; Girault, H. H. Micropatterning of biomolecules on polymer substrates. Langmuir 1998, 14, 5526-5531.

78. Rossier, J. S.; Bercier, P.; Schwarz, A.; Loridant, S.; Girault, H. H. Topography, crystallinity, and wettability of photoablated PET surfaces. Langmuir 1999, 15, 5173-5178.

79. Yamamoto, K.; Asada, T.; Nishide, H.; Tsuchida, E. The Preparation of poly(dihydroxyphenylene) through the electrooxidative polymerization of hydroquinone. Bull. Chem. Soc. Jpn. 1990, 63, 1211-1216. 
80. Bard, A. J.; Faulkner, L. R. Electrochemical methods, fundamentals, and applications, 2nd ed.; John Wiley and Sons: New York, 2001.

81. Andrieux, C. R.; Savéant, J. M. Electrochemical reactions. In Investigation of rates and mechanisms of reactions; Part II, Vol. VI. Bernasconi, C. Ed.; Wiley: New York, 1986; pp 305-389.

82. DigiSim; BAS Instruments Ltd: Warwickshire, UK.

83. Rudolph, M.; Reddy, D. P.; Feldberg, S. W. A simulator for cyclic voltammetric responses. Anal. Chem. 1994, 66, A589-A600.

84. Brookes, B. A.; Lawrence, N. S.; Compton, R. G. Microdisk electrode voltammetry: Theoretical characterization and experimental verification of a novel electrocatalytic mechanism. J. Phys. Chem. B 2000, 104, 11258-11267.

85. Brookes, B. A.; White, P. C.; Lawrence, N. S.; Compton, R. G. Voltammetric sensing of thiols. The electrocatalytic oxidation of 4-acetamidophenol in the presence of cysteine: A mechanistic rotating disk electrode study. J. Phys. Chem. B 2001, 105, 6361-6366.
86. Flux-Expert; Astek Rhone-Alpes: ambernier@astek.fr, F38130 Echirolles, France.

87. Dayon, L.Roussel, C.Girault, H. H. On-line electrochemical tagging of free cysteines in peptides during nanospray ionisation mass spectrometry: An overview. Chimia 2004, 58, 204-207.

88. Babu, K. R.; Moradian, A. Douglas, D. J. The methanolinduced conformational transitions of beta-lactoglobulin, cytochrome $c$, and ubiquitin at low $\mathrm{pH}$ : A study by electrospray ionization mass spectrometry. J. Am. Soc. Mass Spectrom. 2001, 12, 317-328.

89. Ragona, L.; Fogolari, F.; Romagnoli, S.; Zetta, L.; Maubois, J. L.; Molinari, H. Unfolding and refolding of bovine beta-lactoglobulin monitored by hydrogen exchange measurements. $J$. Mol. Biol. 1999, 293, 953-969.

90. Perkins, D. N.; Pappin, D. J. C.; Creasy, D. M.; Cottrell, J. S. Probability-based protein identification by searching sequence databases using mass spectrometry data. Electrophoresis 1999, $20,3551-3567$. 